\title{
Modeling dissolved organic carbon in temperate forest soils: TRIPLEX-DOC model development and validation
}

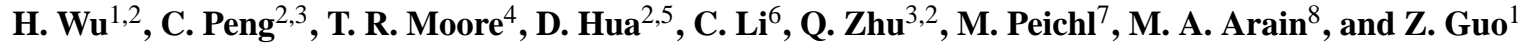 \\ ${ }^{1}$ Key Laboratory of Cenozoic Geology and Environment, Institute of Geology and Geophysics, Chinese Academy of Science, \\ P.O. Box 9825, Beijing 100029, China \\ ${ }^{2}$ Department of Biology Sciences, Institute of Environment Sciences, University of Quebec at Montreal, C.P. 8888, Succ. \\ Centre-Ville, Montreal H3C 3P8, Canada \\ ${ }^{3}$ Laboratory for Ecological Forecasting and Global Change, College of Forestry, Northwest A \& F University, Yangling, \\ Shaanxi 712100, China \\ ${ }^{4}$ Department of Geography and Global Environmental and Climate Change Centre, McGill University, Montreal, \\ H3A 0B9, Canada \\ ${ }^{5}$ Center for Climate Research, University of Wisconsin-Madison, Madison, WI 53706, USA \\ ${ }^{6}$ Institute for the study of Earth, Ocean and Space, University of New Hampshire, Durham, NH 03824, USA \\ ${ }^{7}$ Department of Forest Ecology and Management, Swedish University of Agricultural Sciences, Umeå, Sweden \\ ${ }^{8}$ School of Geography and Earth Sciences and McMaster Centre for Climate Change, McMaster University, Hamilton, \\ Ontario L8S 4K1, Canada
}

Correspondence to: H. Wu (haibin-wu@mail.iggcas.ac.cn) or C. Peng (peng.changhui@uqam.ca)

Received: 13 April 2013 - Published in Geosci. Model Dev. Discuss.: 28 June 2013

Revised: 6 January 2014 - Accepted: 1 April 2014 - Published: 14 May 2014

\begin{abstract}
Even though dissolved organic carbon (DOC) is the most active carbon (C) cycling in soil organic carbon (SOC) pools, it receives little attention from the global $\mathrm{C}$ budget. DOC fluxes are critical to aquatic ecosystem inputs and contribute to the $\mathrm{C}$ balance of terrestrial ecosystems, but few ecosystem models have attempted to integrate DOC dynamics into terrestrial $\mathrm{C}$ cycling. This study introduces a new process-based model, TRIPLEX-DOC, that is capable of estimating DOC dynamics in forest soils by incorporating both ecological drivers and biogeochemical processes. TRIPLEXDOC was developed from Forest-DNDC, a biogeochemical model simulating $\mathrm{C}$ and nitrogen $(\mathrm{N})$ dynamics, coupled with a new DOC process module that predicts metabolic transformations, sorption/desorption, and DOC leaching in forest soils. The model was validated against field observations of DOC concentrations and fluxes at white pine forest stands located in southern Ontario, Canada. The model was able to simulate seasonal dynamics of DOC concentrations and the magnitudes observed within different soil layers, as well as DOC leaching in the age sequence of these forests. Additionally, TRIPLEX-DOC estimated the effect of forest harvesting
\end{abstract}

on DOC leaching, with a significant increase following harvesting, illustrating that land use change is of critical importance in regulating DOC leaching in temperate forests as an important source of $\mathrm{C}$ input to aquatic ecosystems.

\section{Introduction}

Recent climatic change projections have led to a great deal of attention being paid to carbon (C) cycling patterns and controls, particularly those factors that determine whether an ecosystem, from catchment to regional scales, is a net source or sink of atmospheric carbon dioxide $\left(\mathrm{CO}_{2}\right)$ (e.g., Jenerette and Lal, 2005; Chapin III et al., 2006; Cole et al., 2007; Buffam et al., 2011). Northern ecosystems have been identified as being especially important for $\mathrm{CO}_{2}$ exchanges that take place between land and the atmosphere, with temperate forests regarded as a potential $\mathrm{C}$ sink (Chapin III et al., 2000; Dunn et al., 2007). In contrast to terrestrial ecosystems, temperate aquatic ecosystems are a net $\mathrm{C}$ source owing to the mineralization of organic $\mathrm{C}$ imported 
from terrestrial ecosystems and the resultant degassing of inorganic C in lakes and streams (Sobek et al., 2003; Roehm et al., 2009; Humborg et al., 2010; Kosten et al., 2010; Butman and Raymond, 2011; Trolle et al., 2012; Lapierre and del Giorgio, 2012). Only a handful of studies have attempted to comprehensively integrate terrestrial watershed $\mathrm{C}$ balances with their aquatic components. As a result, net ecosystem exchanges (NEE) of temperate terrestrial ecosystems are typically investigated without taking into account $\mathrm{C}$ runoff to aquatic ecosystems and the resultant $C$ loss. Therefore, an integrative approach to examine $\mathrm{C}$ budgets for both terrestrial and aquatic ecosystems will help us to understand and estimate net $\mathrm{C}$ balances on both catchment and regional scales (Grimm et al., 2003; Jenerette and Lal, 2005; Chapin III et al., 2006; Cole et al., 2007; Buffam et al., 2011).

Understanding the interactive dynamics between terrestrial and aquatic ecosystems has been hampered by uncertainties. Processing dissolved organic carbon (DOC) is one such uncertainty (Hanson et al., 2004; Chapin III et al., 2006; Cole et al., 2007; Buffam et al., 2011). DOC plays a key role in the transport of soil nutrients (Qualls et al., 1991; Kaiser et al., 2001; Kaiser and Kalbitz, 2012), leaching from the forest litter layer into mineral soil and then discharged into streams and lakes. Globally, terrestrial ecosystem DOC export to oceans was estimated at approximately 0.17 to 0.36 $\mathrm{Pg} \mathrm{C} \mathrm{yr}^{-1}$ (Aitkenhead and McDowell, 2000; Harrison et al., 2005; Dai et al., 2012). Although DOC exports to water bodies are small relative to other terrestrial C fluxes (Neff and Asner, 2001; Cole et al., 2007), they are nonetheless critical to $\mathrm{C}$ biogeochemical cycling and budgets in aquatic ecosystems (del Giorgio et al., 1999; Hanson et al., 2004; McCallister and del Giorgio, 2008).

Disturbances in the forested watershed or catchments resulting from forest management activities can alter biogeochemical processes in soils by changing species composition, soil characteristics, soil moisture and soil temperature regimes, soil microbial activity, and water flux, thereby potentially causing extensive alterations to occur to soil DOC dynamics (Kreutzweiser et al., 2008). Little attention has been paid to the question of how DOC concentrations, fluxes, and chemistry vary with land use and forest management practices.

In the past decade, considerable progress has been made in modeling approaches used to estimate DOC flux, such as improvements in soil and watershed C dynamics (Boyer et al., 1996; Currie and Aber, 1997; Band et al., 2001; Raymond and Saiers, 2010; Xu et al., 2012). Models have used a variety of physical and chemical watershed properties to predict DOC concentration or export, either regionally or globally, based on empirical relationships between DOC and watershed attributes. Examples are basin size and slope (Clair et al., 1994; Clair and Ehrman, 1996), soil characteristics (Nelson et al., 1993; Hope et al., 1997; Aitkenhead et al., 1999; Aitkenhead and McDowell, 2000), and land cover type (Eckhardt and Moore, 1990; Dillon and Molot, 1997;
Aitkenhead et al., 1999). However, these empirical models often contain numerous environmental variables, some of which may be qualitative in nature, making it impossible to apply to conditions of climate change and human activity over long time spans. To overcome the shortcomings of empirical models, simplistic, process-based mechanistic models that couple hydrological, biological, and geochemical processes have been developed to predict DOC dynamics (Band et al., 2001; Xu et al., 2012).

A handful of more complex process-based soil DOC models have recently been developed. Neff and Asner (2001), for example, proposed a model related to DOC transport for terrestrial ecosystems, involving rates of production of DOC by vegetation and organic soil compounds, soil profile transport, mineral soil horizon adsorption, and the eventual export from a system. Michalzik et al. (2003) relied on ${ }^{14} \mathrm{C}$ data to determine the age of soil organic matter. Lumsdon et al. (2005) simulated changing organic matter solubility as a function of competitive cation adsorption and hydrophobicity in a single soil horizon. Although these DOC models reasonably simulate soil DOC dynamics, they are currently incapable of investigating the potential impacts of land use change on the fate of DOC, such as forest management practices.

The broad aim in this study is to develop a general and quantitative approach at the landscape scale to simulate changes in soil DOC concentration and flux resulting primarily from successional changes in forest type, productivity, aboveground biomass, litterfall, and forest floor biomass accumulation through stand development. The specific objectives are (a) to introduce the development of TRIPLEXDOC, a new DOC process-based model was used in conjunction with the forest soil $\mathrm{C}$ model to simulate seasonal and annual DOC concentration and flux patterns from precipitation to subsoil seepage, and (b) to assess land use impacts on dynamics and temporal changes in DOC soil leaching.

\section{Model description and methods}

DOC concentrations and fluxes were assigned for a vertical profile for a given forest ecosystem as follows (see Fig. 1): input through precipitation and throughfall; forest floor biological production and leaching; subsequent transfer to soil A, $\mathrm{B}$, and $\mathrm{C}$ layers, including physical sorption/desorption processes; and the eventual export from a given forest ecosystem.

Figure 1 provides an overall structure and framework of TRIPLEX-DOC, which includes forest growth, soil carbon, hydrological and thermal conditions, and DOC dynamics simulation. This model is primarily based on Forest-DNDC (Li et al., 2000), a process-based biogeochemical model that simulates $\mathrm{C}$ and $\mathrm{N}$ dynamics and trace gas emissions in upland forest ecosystems.

The forest growth submodel (Li et al., 2000) was adopted from the PnET model (Aber and Federer, 1992), a forest 


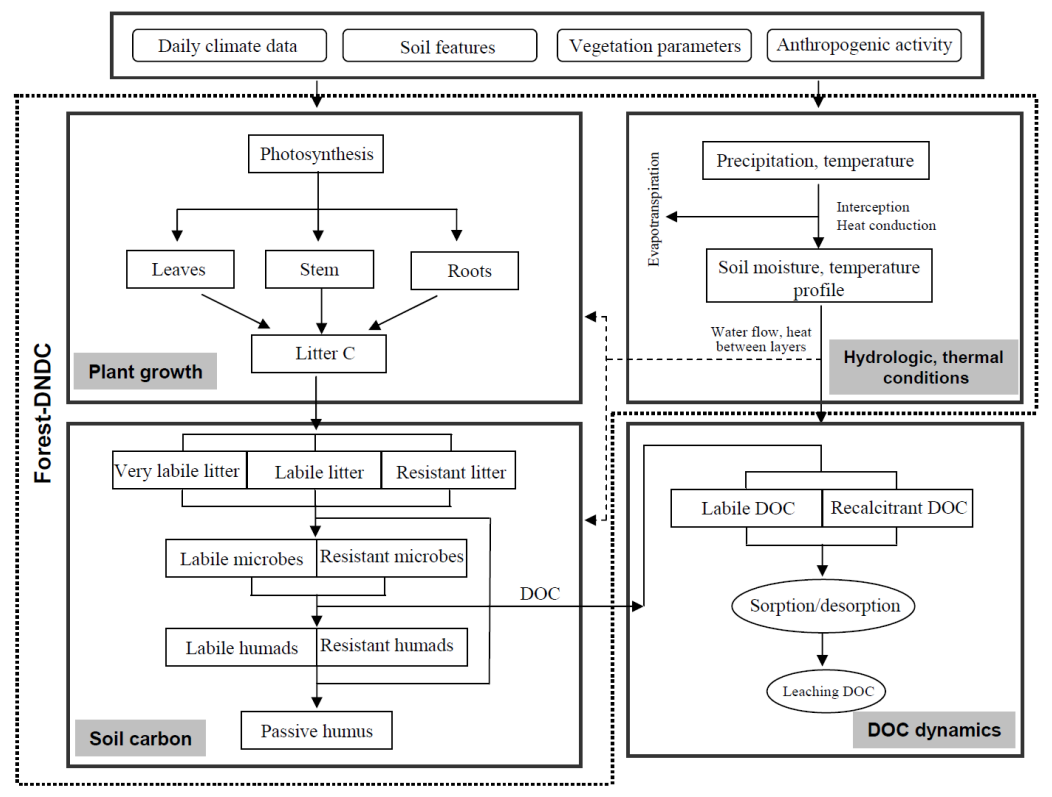

Fig. 1. Modular structure of TRIPLEX-DOC. The model is composed of four submodels that predict forest growth, soil hydrologic and thermal conditions, $\mathrm{C}$ decomposition, and DOC dynamics. The simulations of forest growth, soil carbon, and hydrological and thermal conditions were adopted from the Forest-DNDC model; the DOC dynamics simulation is the newly redesigned submodel.

physiology model developed to predict forest photosynthesis, respiration, organic $\mathrm{C}$ production and allocation, and litter production. This submodel is driven by solar radiation, temperature, and water and $\mathrm{N}$ availability, and transfers litter production, water and $\mathrm{N}$ demands, and root respiration data to the soil climate submodel or the decomposition submodel.

Soil $\mathrm{C}$ is divided into three organic matter pools ( $\mathrm{Li}$ et al., 2000): residues (primary plant residues), microbial biomass, and humads. Each pool has both a labile and resistant component (Fig. 1). Soil organic matter (SOM) content is related to litter quantity and quality. The forest growth submodel predicts litter production and the litter $\mathrm{C} / \mathrm{N}$ ratio. After litterfall, the decomposition submodel allocates fresh litter to the very labile, labile, and resistant litter pools based on the litter C/ N ratio, then quantifies the decomposition of organic matter resulting in DOC substrate concentrations, ammonium $\left(\mathrm{NH}_{4}^{+}\right)$, nitrate $\left(\mathrm{NO}_{3}^{-}\right)$, and $\mathrm{CO}_{2}$, based on decay rates ( $k$ values) that are dependent on organic matter quality and soil environmental conditions (e.g., soil temperature, soil moisture, and clay content in soil).

The soil climate submodel converts daily climate data into soil temperature and moisture profiles and is used to calculate soil oxygen availability within the forest soil profile. The hydrological submodel (Li et al., 2000) simulates soil water flux. The soil profile is divided into layers exhibiting different characteristics (e.g., organic soils and mineral soils). This submodel takes into account water input (e.g., precipitation, surface inflow, snow and ice melt), output (evaporation and transpiration), runoff, and water transfer within the unsaturated zone (infiltration, gravity drainage, and matrix redistribution).

Forest-DNDC has previously been used to successfully predict trace gas emissions in regional studies (Kesik et al., 2005; Kiese et al., 2005) and effects of forest management practices on soil environmental factors (Sun et al., 2006; Dai et al., 2012). Additionally, the model is currently parameterized for 12 forest ecosystem tree species/genera: pine, spruce, hemlock, fir, hardwoods, oak, birch, beech, slash pine, larch, cypress, and evergreen oak (Li et al., 2000). It is particularly useful when investigating DOC dynamics for different forest types at a landscape level.

Although Forest-DNDC was developed to competently administer the production of DOC by microorganisms associated with litter $\mathrm{C}$, microbial biomass, and humads decomposition ( $\mathrm{Li}$ et al., 2000), the model does not include throughfall DOC production. Because mean annual concentrations of DOC in throughfall are between 3 and $35 \mathrm{mg} \mathrm{L}^{-1}$ in temperate forests, and the fluxes of DOC range from 40 to $160 \mathrm{~kg} \mathrm{DOC} \mathrm{ha}^{-1} \mathrm{yr}^{-1}$ (Michalzik et al., 2001), it is an important source that derives as rainfall passes through forest canopies. Moreover, Forest-DNDC also does not adequately estimate DOC consumption and does not include the capacity to simulate sorption/desorption, two key processes that determine DOC decomposition and stabilization in soils (Neff and Asner, 2001). As a result, Forest-DNDC overestimates DOC concentrations in different soil layers (Fig. 2) and makes it impossible to reliably simulate DOC leaching from soils. To overcome these shortcomings, the DOC dynamics submodel incorporates a more precise algorithm describing 


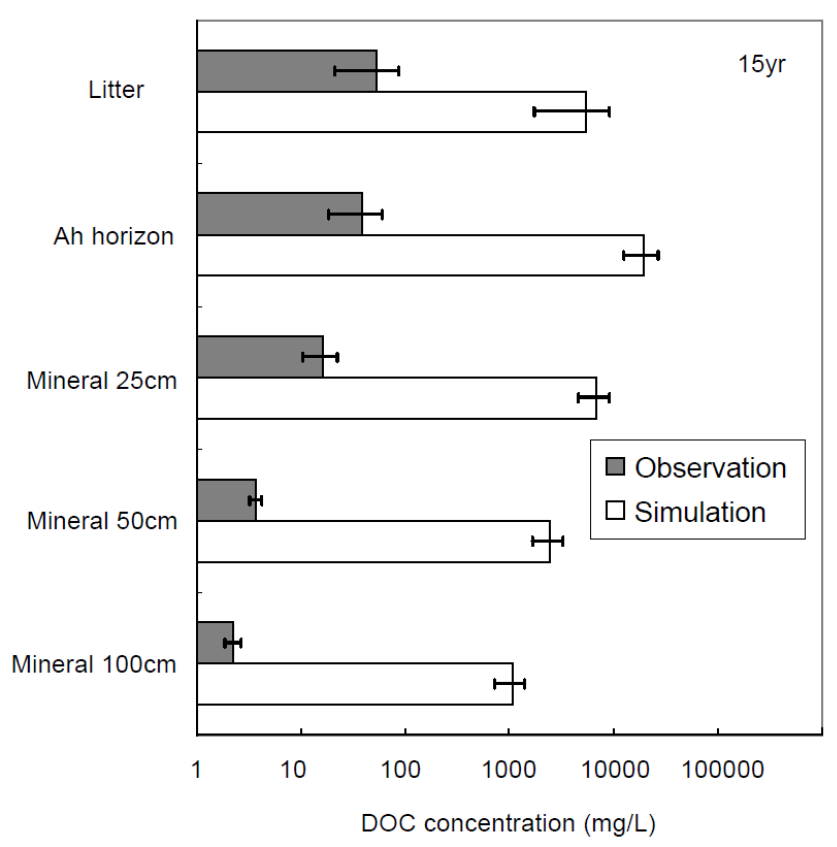

Fig. 2. Comparison of annual mean DOC concentrations in different soil layers between Forest-DNDC simulations (Li et al., 2000) and field measurements in a 15-year-old temperate pine forest in southern Ontario.

contributions of throughfall, DOC consumption, and DOC sorption/desorption was integrated into Forest-DNDC. The new model is named as TRIPLEX-DOC, which is more suitable for predicting forest soil DOC metabolic transformations, sorption/desorption, and leaching in changing environmental conditions.

Soil C pools and decomposition processes, forest growth, and hydrological dynamics have been well documented and are described in detail in the DNDC (Li et al., 1992), PnET (Aber and Federer, 1992), and Forest-DNDC models (Li et al., 2000). However, the scope of this study was only to describe DOC processes and the newly redesigned TRIPLEXDOC, including DOC production and consumption as well as sorption/desorption.

\subsection{DOC production and consumption submodel}

The biological production and consumption of DOC play an important role in the regulation of soil DOC flux. DOC production via throughfall was calculated as follows:

$\mathrm{DOC}_{\text {Interception }}=R_{\mathrm{i}} \times[\mathrm{DOC}]$,

where $\mathrm{DOC}_{\text {Interception }}$ is DOC production via throughfall; DOC is the concentration in throughfall; and $R_{\mathrm{i}}$ is interception, a highly simplified function based on the leaf area index (LAI) by Rutter et al. (1971). The other production processes of DOC by microorganisms associated with litter $C$, root exudates, and humified organic matter were adopted from Forest-DNDC (Li et al., 2000).
The major factors affecting DOC biodegradation and the size of these pools included its molecular size, chemical composition (e.g., quantities of carbohydrates, lignin, etc.), polarity, and acidity, as well as the chemical characteristics of the solution itself, such as $\mathrm{pH}$, nutrient content, and oxygen and metal concentrations (Marschner and Kalbitz, 2003). Because the estimates of decomposition rates are difficult to model by a simple approach considering all the abovementioned factors, numerous studies have focused on DOC fractions that decompose over a range of time spans (Dahm, 1981; Zsolnay and Steindl, 1991; Qualls and Haines, 1992; Jandl and Sollins, 1997; Yano et al., 1998; Kalbitz et al., 2003). Two kinetically distinct pools of biodegradable DOC have been recognized as fast and slow, and a double exponential equation for two distinct DOC pools with different mineralization rate constants fitted well to the measured data (Qualls and Haines, 1992; Kalbitz et al., 2003; Kiikkila et al., 2006; McDowell et al., 2006).

$\operatorname{DOC}_{\text {remain }}(\%)=(100-b) \times 10^{-k_{1} t}+b \times 10^{-k_{2} t}$,

where $t$ is time (units of day); $100-b$ and $b$ are the initial percentages of rapidly and slowly decaying components, respectively; and $k_{1}$ and $k_{2}$ are the rate constants of the two components determined from a range of litters and soils in Canadian forests (Turgeon, 2008).

\subsection{DOC sorption/desorption submodel}

Sorption and desorption are two key processes related to soil DOC stabilization and production. Because DOC continuously moves in and out of solutions in soil, the initial mass (IM) isotherm best represents DOC sorption reactions (Nodvin et al., 1986; Kaiser et al., 1996). This is described by the following linear isotherm:

$\mathrm{RE}=m X_{\mathrm{i}}-b$,

where RE is the amount of DOC released into or removed from a solution, $m$ is the dimensionless regression parameter, $X_{\mathrm{i}}$ is the initial concentration of DOC $\left(\mathrm{mg} \mathrm{g} \mathrm{soil}^{-1}\right)$, and $b$ is the intercept (mg DOC released per gram of soil when $X_{\mathrm{i}}=0$ ). Functionally, $m$ and $b$ can be viewed as measures of the tendency of soil to adsorb and release DOC. This linear sorption isotherm model is the most widely used by researchers and successfully describes the dissolved organic matter (DOM) sorption phenomena in soil horizons with low sorption capacity or cases that occur within a narrow concentration range (Vandenbruwane et al., 2007).

For DOC, the affinity of soils is closely linked to a number of soil properties. Generally, there are positive correlations between $m$ and soil clay content, dithionite extractable iron, and oxalate extractable aluminum (Moore et al., 1992; Nelson et al., 1993; Kaiser et al., 1996; Kaiser and Zech, 1998; Kothawala et al., 2009). Pedotransfer functions (PTF) used in estimating the two parameters ( $m$ and $b$ ) were 
developed by Moore et al. (1992):

$$
\begin{aligned}
m_{o} & =0.451+0.02 \log \left(\mathrm{Fe}_{\mathrm{cbd}}\right)+0.032 \sqrt{\mathrm{Al}_{\mathrm{ox}}} \\
& +0.064 \log (\mathrm{OC})
\end{aligned}
$$

$$
\begin{aligned}
b_{o} & =0.145+0.103 \log (\mathrm{OC})-0.055 \sqrt{\mathrm{Al}_{\mathrm{ox}}} \\
& -0.045 \log \left(\mathrm{Fe}_{\mathrm{cbd}}\right),
\end{aligned}
$$

where $\mathrm{OC}, \mathrm{Al}_{\mathrm{Ox}}$, and $\mathrm{Fe}_{\mathrm{cbd}}$ denote the contents (in mass \%) of organic $\mathrm{C}$, oxalate extractable aluminum, and dithionitecitrate-bicarbonate extractable iron; soil properties of $\mathrm{Al}_{\mathrm{ox}}$ and $\mathrm{Fe}_{\text {cbd }}$ were established from Canadian soils (Kothawala et al., 2009). Parameters $m$ and $b$ are given as a fraction and in units of $\mathrm{g} \mathrm{kg}^{-1}$, respectively.

Hydrologic conditions influence the leaching and apparent reactivity of DOC. Within soils, factors such as hydraulic conductivity and bypass flow capacity affect the concentration and flux of inorganic elements in a solution (Prendergast, 1995), and it is likely that DOC behaves in a similar manner (Radulivich et al., 1992). Weigand and Totsche (1998) have provided strong evidence that water flow rates through soil layers affect the fate of DOC. A recent analysis of stream discharge and DOM measurements from 30 forested watersheds in the eastern United States revealed the importance of hydrologic events in regulating the transport of DOC to downstream ecosystems (Raymond and Saiers, 2010).

Sorption affinity $m$ is reduced by a modifier $\left(H_{m}\right)$ that scales with the rate of movement of a solution through soil:

$m=m_{o}-H_{m}$.

This parameterization denotes a kinetic aspect of sorption reaction and a maximum flow rate induced variation in $m$ of $20 \%$ for soils with a $100 \%$ clay content:

$H_{m}=m_{o} \times 0.2 \times\left(\frac{v}{v_{\mathrm{s}}}\right) \times\left(\frac{\% \text { Clay }}{100}\right)$,

where $v$ is the actual pore water velocity and $v_{\mathrm{s}}$ is the pore water velocity in saturated conditions (a soil-specific parameter). These parameters were established from Forest-DNDC (Li et al., 2000). The equation scales with clay content because the rate of sorption does not appear to be affected by hydrologic flux rates in sandy soils (Weigand and Totsche, 1998).

In contrast to sorption flux, desorption flux appears to be driven by concentration gradients that increase with solution flow (Weigand and Tosche, 1998). Thus, $b$ is increased and calculated as follows:

$b=b_{o}+H_{b}$,

$H_{b}=b_{o} \times 0.2 \times\left(\frac{v}{v_{\mathrm{s}}}\right) \times\left(\frac{\% \text { Clay }}{100}\right)$.

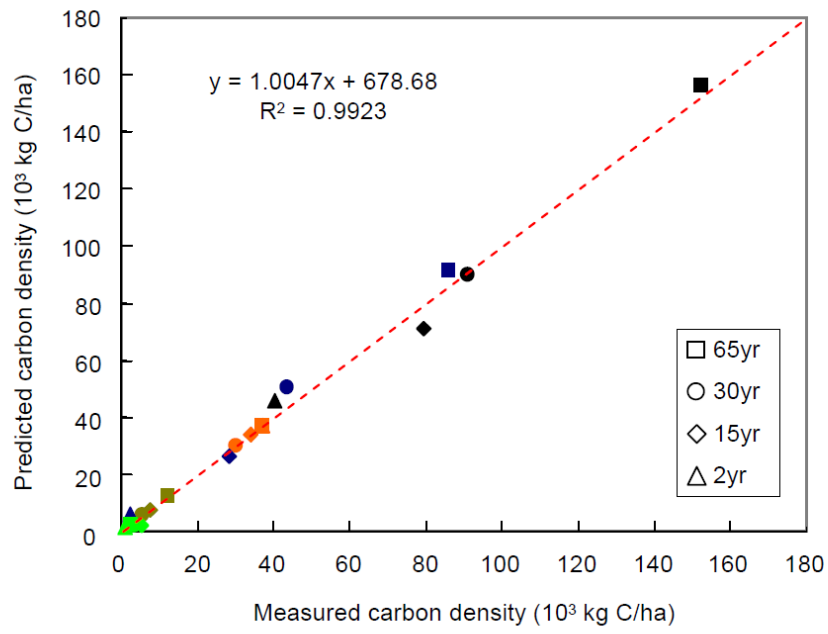

Fig. 3. Observed versus predicted $\mathrm{C}$ densities in foliage (green), wood (blue), forest floor (dark yellow), soil (orange), and the summed total (black) in an age sequence of temperate pine forests in southern Ontario.

As it is with the down-regulating $H_{m}$ modifier, $H_{b}$ scales with flow velocity and clay content; however, in contrast to how flow affects $m, b$ is incremented by $H_{b}$, establishing a flow-dependent desorption coefficient.

The above DOC submodel was incorporated into ForestDNDC to simulate DOC flux in temperate forest soils. The program of DOC submodel was developed using the $\mathrm{C}^{++}$ language as used in the Forest-DNDC. The Forest-DNDC model is available at http://www.dndc.sr.unh.edu, and its program code is not changed in this study. For simulations, the soil profile $(1.0 \mathrm{~m})$ was divided into horizontal layers with a typical thickness of $4 \mathrm{~cm}$. Each layer was assumed to have uniform properties (e.g., temperature, moisture, substrate and microbe concentrations, etc.), and all decomposition calculations were carried out layer by layer. The model was run in a daily time step.

\section{Model input and validation data}

TRIPLEX-DOC inputs and file format are same as ForestDNDC model, including daily climate data (maximum and minimum temperature, and precipitation), soil properties (soil type, soil texture, and $\mathrm{pH}$ ), and forest characteristics and management (forest type, stand age, and percentage of trees removed or harvested).

DOC data used to test and validate our model were measured at the Turkey Point Flux Station and have been reported in Peichl et al. (2007). These data provided an opportunity to quantify the role of DOC in upland forest ecosystems and through comparisons between sites to identify critical controls as well as to test model performance. Turkey Point Flux Station is located on the northern shore of Lake Erie in southern Ontario, Canada (Arain and Restrepo-Coupe, 2005; 
Table 1. Soil and stand characteristics of an age sequence of temperate pine forests in southern Ontario.

\begin{tabular}{|c|c|c|c|c|}
\hline Characteristics & 65 years old & 30 years old & 15 years old & 2 years old \\
\hline Location & $42.7098^{\circ} \mathrm{N}, 80.3574^{\circ} \mathrm{W}$ & $42.7068^{\circ} \mathrm{N}, 80.3483^{\circ} \mathrm{W}$ & $42.7742^{\circ} \mathrm{N}, 80.4588^{\circ} \mathrm{W}$ & $42.6609^{\circ} \mathrm{N}, 80.5595^{\circ} \mathrm{W}$ \\
\hline $\begin{array}{l}\text { Dominant tree } \\
\text { species }\end{array}$ & $\begin{array}{l}\text { White pine } \\
\text { (Pinus strobes) }\end{array}$ & $\begin{array}{l}\text { White pine } \\
\text { (Pinus strobes) }\end{array}$ & $\begin{array}{l}\text { White pine } \\
\text { (Pinus strobes) }\end{array}$ & $\begin{array}{l}\text { White pine } \\
\text { (Pinus strobes) }\end{array}$ \\
\hline $\begin{array}{l}\text { Major understory } \\
\text { vegetation species }\end{array}$ & $\begin{array}{l}\text { Quercus vultina, } \\
\text { Abies balsamifera, } \\
\text { Prunus serotina }\end{array}$ & Quercus vultina & Quercus vultina & none \\
\hline Max. LAI $\left(\mathrm{m}^{2} \mathrm{~m}^{-2}\right)$ & 8.0 & 5.9 & 12.8 & 1.0 \\
\hline Mean tree height (m) & 22 & 12 & 9 & 1 \\
\hline $\begin{array}{l}\text { Mean tree diameter } \\
\text { at } \mathrm{DBH}(\mathrm{cm})\end{array}$ & 35 & 16 & 16 & 2.5 (tree base) \\
\hline $\begin{array}{l}\text { Stem density } \\
\left(\text { trees ha }^{-1}\right)\end{array}$ & 429 & 1492 & 1242 & 1683 \\
\hline $\begin{array}{l}\text { Aboveground tree } \\
\text { biomass }\left(\mathrm{g} \mathrm{C} \mathrm{m}^{-2}\right)\end{array}$ & 8416 & 4488 & 3236 & 22 \\
\hline $\begin{array}{l}\text { Forest floor } \\
\left(\mathrm{g} \mathrm{C} \mathrm{m}^{-2}\right)\end{array}$ & 1211 & 545 & 745 & 83 \\
\hline $\begin{array}{l}\text { Forest floor } \\
\text { thickness }(\mathrm{cm})\end{array}$ & 2.5 & 2.0 & 3.0 & 0.5 \\
\hline $\begin{array}{l}\text { Tree roots } \\
(>2 \mathrm{~mm})\end{array}$ & 1920 & 923 & 502 & 5 \\
\hline $\begin{array}{l}\text { Litterfall } \\
\text { throughout } \\
2004-2005 \\
\left(\mathrm{~g} \mathrm{C} \mathrm{m}^{-2} \text { year }^{-1}\right)\end{array}$ & $340-400$ & $220-290$ & $440-520$ & no data \\
\hline \multirow[t]{2}{*}{ Soil type } & Brunisolic & Brunisolic & Gleyed Brunisolic & Brunisolic \\
\hline & Luvisol & Luvisol & Luvisol & Luvisol \\
\hline Soil texture & Fine sandy & Fine sandy & Fine sandy loam & Fine sandy \\
\hline $\begin{array}{l}\text { Soil pH } \\
\text { (upper } 20 \mathrm{~cm} \text { ) }\end{array}$ & 5.5 & 5.5 & 6.2 & 7.4 \\
\hline $\begin{array}{l}\text { Soil C } \\
\left(\mathrm{g} \mathrm{C} \mathrm{m}^{-2}\right)\end{array}$ & 3700 & 3000 & 3400 & 3700 \\
\hline
\end{tabular}

Data from Peichl and Arain (2006) and Peichl et al. (2007).

Peichl et al., 2010). It consists of four eastern white pine ( $\mathrm{Pi}$ nus strobus L.) forests that were planted in 2002 (2 years old), 1989 (15 years old), 1974 (30 years old), and 1939 (65 years old), respectively. All four stands are located within a $20 \mathrm{~km}$ radius of each other. The average altitude of the sites is $220 \mathrm{~m}$, the 30 -year mean annual temperature is $7.8^{\circ} \mathrm{C}$, and annual precipitation is $1010 \mathrm{~mm}$, of which $438 \mathrm{~mm}$ falls from May to September (Environment Canada norms from 1971 to 2000 taken at Delhi, Ontario). Mean annual snowfall is $133 \mathrm{~cm}$, the mean annual frost-free period is 160 days, and the mean growing season length is approximately 212 days (Presant and Acton, 1984). Turkey Point sites are situated on lacustrine sandy plains with Brunisolic Luvisol and Gleyed Brunisolic Luvisol sandy soils (about $98 \%$ sand, $1 \%$ silt, $1 \%$ clay) that are well drained and have low-to-moderate water holding capacity. Meteorological and soil temperature and soil moisture (at several depths at two locations at each site) data were collected at all four age-sequence sites using automatic weather stations. Further site and instrumentation details are given in Table 1 and Peichl and Arain (2006) and Peichl et al. (2010).

DOC data used in our study were collected at monthly intervals from the end of May to the end of November 2004 and at biweekly intervals from early April to November 2005 and from April to mid-May 2006. Throughfall DOC was collected in plastic buckets equipped with a $10 \mathrm{~cm}$ radius funnel with necks fitted with glass wool. Leachates from beneath the forest floor and the organic-rich Ah horizon were sampled using zero-tension lysimeters. Porous cup suction lysimeters at 25,50 , and $100 \mathrm{~cm}$ depth were used to sample mineral soils. A detailed description of DOC measurements is given in Peichl et al. (2007).

To mimic forest harvesting, a model simulation was performed for an 80 -year-old stand where $50 \%$ of the trees were excluded, while biomass was left on the forest floor. 

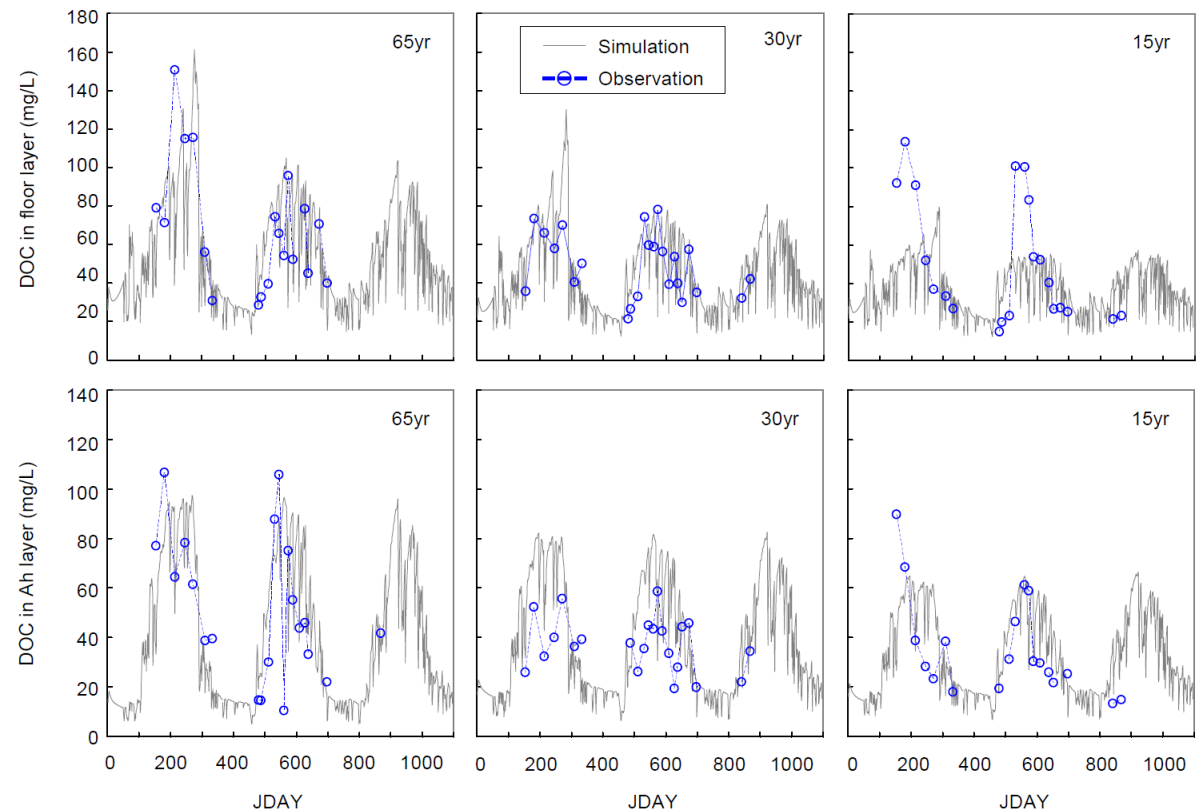

Fig. 4. Time series of measured daily DOC concentrations versus simulated values in litter layer and Ah soils layer in an age sequence of temperate pine forests in southern Ontario.

\section{Model validation}

\subsection{Carbon density at different forest ages}

The model was run along a series of different forest ages, applying default forest parameter settings of pine ( $\mathrm{Li}$ et al., 2000) for temperate forest growth. Figure 3 shows simulation results for 2-, 15-, 30-, and 65-year-old white pine stands compared to observed $\mathrm{C}$ density in foliage, wood, forest floor, and soil. Values approximate to $1: 1$, indicating that the forest growth submodel performed well and therefore has the potential to predict temperate pine forest growth for different stand ages.

\subsection{DOC concentrations and leaching in different soil layers}

Temporal variation in soil water DOC concentrations and fluxes were simulated and the model was able to capture reasonably well the temporal variations (maximum in summer and minimum in winter) in DOC concentrations in the forest floor or litter layer compared to observations at the 65and 30-year-old forests (Fig. 4). However, model simulations yielded less temporal variation in DOC concentrations than observed in summer for a 15-year-old forest stand. Model simulations showed good agreement with field observations of DOC in the Ah layer with respect to seasonality and magnitude for the 65- and 15-year-old forest stands but yielded lower DOC concentrations in summer than observed in the 30-year-old forest stand (Fig. 4).
Model simulations showed that DOC concentrations throughout a 1-year period clearly decreased from the litter layer, to the A horizon and the B mineral horizon, reasonably consistent with observations for both the 65- and 15-year-old forest stands for which data had been previously measured (Fig. 5).

Simulated DOC leaching from forests of 2-, 15-, 30-, and 65-year-old stands (Fig. 6) showed a deceasing trend with increasing stand age, in good agreement with field observations throughout the age-sequence investigation. Overall performance indicated that the model was able to capture the primary mechanisms responsible for the variability and dynamics in observed DOC concentrations and leaching in these white pine forest soils.

\subsection{Sensitivity analysis}

A variety of equations have been used within TRIPLEXDOC to numerically describe processes involved in C cycle and DOC leaching in forest ecosystems and to quantify their sensitivity to environmental factors. A sensitivity analysis examined the impact of changes in environmental conditions (sorption $(m)$ and desorption $(b)$ parameters, daily maximum and minimum temperature, and precipitation) on eight model predictions (net primary productivity (NPP), total biomass, floor carbon, soil carbon, annual mean DOC concentration in floor layer, annual mean DOC concentration in Ah layer, annual mean DOC concentration in mineral $50 \mathrm{~cm}$, and DOC leaching) that are considered to be the most important variables for overall forest $\mathrm{C}$ dynamics and DOC processes in soil at different age forests. It provides an opportunity to test 


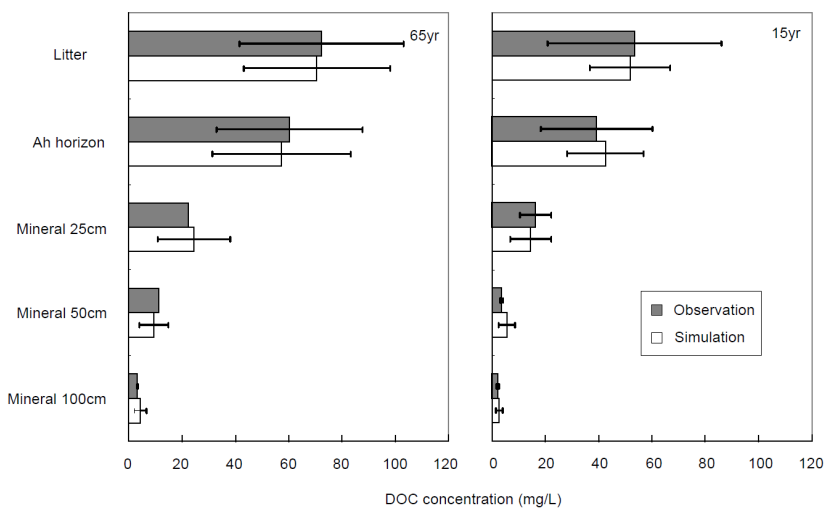

Fig. 5. Measured versus simulated annual mean DOC concentrations in soils in 65- and 15-year-old temperate pine forests in southern Ontario. Error bars denote standard deviations.

the basic behavior of the new model. The DOC concentration sensitivity to sorption $(m)$ and desorption $(b)$ parameters was tested by a simple halving and doubling in values (four experiments each for the forest floor layer and $\mathrm{Ah}$ layer) for each as the range limits (Fig. 7). The sensitivity for other model drivers was addressed by varying one factor and keeping all others constant, applying a $1^{\circ}$ increase/decrease in daily maximum and minimum temperature, and a $10 \%$ increase/decrease in precipitation to baseline scenarios (Table 2).

Figure 7 shows the DOC concentration sensitivity experiments to variation in sorption $(m)$ and desorption $(b)$ using the Taylor diagram (Taylor, 2001). The correlation coefficients were used to quantify the similarity between simulated and observed DOC patterns. The normalized standard deviation (SD) and the centered root-mean-square (rms) difference were used to measure the temporal variability and internal model error of the models, respectively. The position of each letter appearing on the plot quantified how closely that model-simulated DOC concentration patterns matched the observations, and thus the more distance of SD and rms difference between the observational data (dashed arc, reference) and the simulations indicated more sensitivity for the $m / b$ variations. The sensitivity results showed that the correlations with observations were about 0.6 ; the increase (1-3 and 2-3 in Fig. 7) and decrease (1-2 and 2-2) sorption parameter $(m)$ had greater effect on DOC concentrations in different soil layers than the variation ( $1-5$ and $2-5$ for increase, 1-4 and 2-4 for decrease) of desorption parameter (b), suggesting the response of DOC concentration to sorption was more significant than the response to desorption in temperate forest soils.

As expected, NPP and total biomass for all forests ages responded positively to increases in both daily minimum temperature and precipitation (Table 2). A $1^{\circ}$ increase in minimum temperature resulted in the increases of 1.9 to $7.5 \%$ and 2.8 to $9.2 \%$ in NPP and total biomass, respectively, with

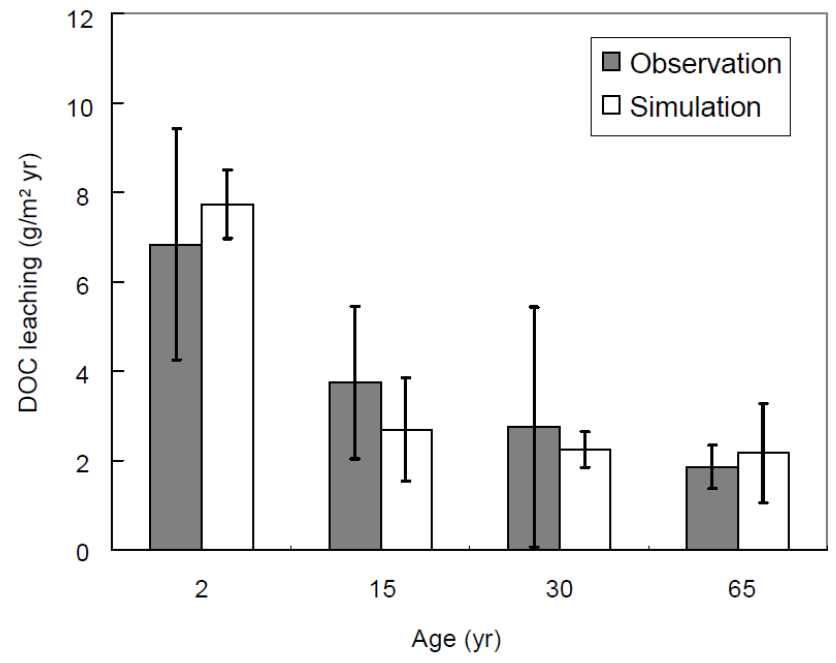

Fig. 6. Comparison between measured and simulated annual DOC leaching in an age sequence of temperate pine forests in southern Ontario. Error bars denote standard deviations.

more response for the young forests. The responses of NPP and total biomass to a $10 \%$ increase in precipitation were less pronounced (only 0.1 to $3.1 \%$ increase). On the other hand, the NPP and total biomass responded negatively to increases in the maximum temperature. The model predictions of positive soil carbon responses with decreasing temperature and precipitation were also observed (Table 2).

The annual mean DOC concentrations in the forest floor layer, Ah layer, and in mineral soil responded negatively to changes in the minimum temperature and precipitation. However, this relationship was reversed to changes in the maximum temperature (except the 2-year-old forest). The DOC leaching responded positively to the increase of precipitation for all four forest ages. The response of DOC leaching to precipitation change ( -22.8 to $35.7 \%$ ) was more significant than the response to temperature ( -4.5 to $4.8 \%)$.

\section{Discussion}

\subsection{Comparison to previous models}

The aim of this study was to introduce TRIPLEX-DOC, a newly redesigned process-based model developed to investigate soil DOC processes. It incorporates many of the best features of existing $\mathrm{C}$ processing models, including DOC production and decomposition, sorption/desorption into soil solids, and transport by water percolation. It extends ForestDNDC in predicting $\mathrm{C}$ cycles by including detailed model representations of soil DOC dynamics and leaching.

The key innovations compared to previous DOC models (Neff and Asner, 2001; Michalzik et al., 2003; Lumsdon et al., 2005) are that TRIPLEX-DOC is the first DOC cycling model to explicitly include land cover type effects for 
Table 2. Results of sensitivity of key variables to changes in climatic variables for different-aged temperate pine stands used in this study.

\begin{tabular}{|c|c|c|c|c|c|c|}
\hline \multirow[b]{2}{*}{ Pine stands } & \multicolumn{2}{|c|}{$\begin{array}{l}\text { Minimum } \\
\text { temperature }\end{array}$} & \multicolumn{2}{|c|}{$\begin{array}{l}\text { Maximum } \\
\text { temperature }\end{array}$} & \multicolumn{2}{|c|}{ Precipitation } \\
\hline & $+1^{\circ}$ & $-1^{\circ}$ & $+1^{\circ}$ & $-1^{\circ}$ & $+10 \%$ & $-10 \%$ \\
\hline \multicolumn{7}{|l|}{2 years } \\
\hline NPP & +7.5 & -4.1 & +0.5 & +0.7 & +0.1 & -0.2 \\
\hline Total biomass & +9.2 & -5.3 & 0.0 & +1.1 & +0.1 & -0.2 \\
\hline Floor carbon & -2.1 & +1.4 & -2.2 & +1.5 & -0.2 & +0.3 \\
\hline Soil carbon & -2.3 & +2.3 & -1.3 & +1.1 & -1.9 & +2.3 \\
\hline DOC concentration in floor layer & -3.2 & +2.9 & -3.1 & +2.8 & -1.4 & +1.7 \\
\hline DOC concentration in Ah layer & -3.7 & +4.4 & -1.6 & +1.8 & -4.6 & +5.1 \\
\hline DOC concentration in mineral $50 \mathrm{~cm}$ & -3.8 & +9.1 & +0.2 & +4.8 & -1.0 & +4.4 \\
\hline DOC leaching & -2.8 & +4.8 & -1.4 & +3.6 & +15.7 & -9.7 \\
\hline \multicolumn{7}{|l|}{15 years } \\
\hline NPP & +2.4 & -2.0 & -2.2 & +2.0 & +2.0 & -2.1 \\
\hline Total biomass & +3.3 & -2.8 & -2.9 & +2.4 & +2.4 & -2.6 \\
\hline Floor carbon & +0.2 & +0.3 & 0.0 & +0.6 & +0.9 & -1.0 \\
\hline Soil carbon & -3.1 & +3.1 & -1.6 & +1.3 & -2.7 & +3.5 \\
\hline DOC concentration in floor layer & -1.4 & +1.3 & -0.5 & +0.5 & -2.1 & +3.0 \\
\hline DOC concentration in Ah layer & -1.7 & +1.8 & +0.3 & -0.4 & -3.8 & +4.6 \\
\hline DOC concentration in mineral $50 \mathrm{~cm}$ & -5.2 & +8.3 & +2.7 & -0.1 & -5.5 & +8.7 \\
\hline DOC leaching & -0.1 & +3.2 & -4.3 & +2.8 & +19.6 & -20.2 \\
\hline \multicolumn{7}{|l|}{30 years } \\
\hline NPP & +2.3 & -1.7 & -2.9 & +2.7 & +2.3 & -2.4 \\
\hline Total biomass & +3.0 & -2.5 & -3.5 & +3.0 & +2.7 & -2.6 \\
\hline Floor carbon & +0.6 & 0.0 & +0.4 & +0.2 & +1.0 & -1.2 \\
\hline Soil carbon & -3.0 & +3.2 & -0.8 & +0.7 & -3.0 & +3.8 \\
\hline DOC concentration in floor layer & -0.1 & +0.6 & +1.4 & -1.0 & -2.8 & +3.1 \\
\hline DOC concentration in Ah layer & -1.7 & +1.7 & +1.1 & -1.3 & -4.6 & +5.5 \\
\hline DOC concentration in mineral $50 \mathrm{~cm}$ & -3.8 & +5.9 & +3.9 & -2.2 & -6.6 & +8.1 \\
\hline DOC leaching & -0.9 & -0.7 & -4.5 & -0.4 & +35.7 & -9.0 \\
\hline \multicolumn{7}{|l|}{65 years } \\
\hline NPP & +1.9 & -1.3 & -4.9 & +4.5 & +2.9 & -3.4 \\
\hline Total biomass & +2.8 & -2.3 & -5.1 & +4.4 & +3.1 & -3.3 \\
\hline Floor carbon & +0.6 & 0.0 & +0.5 & +0.2 & +0.9 & -1.0 \\
\hline Soil carbon & -2.1 & +2.6 & 0.0 & +0.4 & -2.1 & +2.8 \\
\hline DOC concentration in floor layer & -0.3 & +0.5 & +1.6 & -1.4 & -3.0 & +3.9 \\
\hline DOC concentration in Ah layer & -1.0 & +1.3 & +2.8 & -2.4 & -4.6 & +5.7 \\
\hline DOC concentration in mineral $50 \mathrm{~cm}$ & -3.1 & +4.8 & +5.0 & -2.9 & -6.1 & +8.8 \\
\hline DOC leaching & -0.3 & -4.9 & -3.6 & -4.4 & +26.1 & -22.8 \\
\hline
\end{tabular}

Values given represent percent of change compared to the baseline scenario.

different forest stand ages, soil C biogeochemistry, and hydrological flow on DOC dynamics. TRIPLEX-DOC was validated using observed data, showing that the model can successfully simulate soil DOC concentrations and leaching for different aged forest stands.

The TRIPLEX-DOC modeled DOC production includes fresh litter, root exudates, and humified organic matter, all of which contribute substantial amounts of belowground DOC (Li et al., 1992; Guggenberger et al., 1994), whereas DOC was produced only from litter in the DocMod model (Currie and Aber, 1997) and only from humified organic matter in the DyDoc model (Michalzik et al., 2003). TRIPLEX-DOC shares similar features to the DOC model (Neff and Asner,
2001) in that both models generate DOC from both litter and soil organic matter. However, estimates from litter in the DOC model (Neff and Asner, 2001) are based on statistical relationships between DOC production and the ratio of lignin to $\mathrm{N}$ in incoming litter, whereas estimates from TRIPLEXDOC are based on Forest-DNDC (Li et al., 2000), a processbased model. In this case, fresh litter is partitioned into very labile, labile, and resistant litter pools based on the input litter $\mathrm{C} / \mathrm{N}$ ratio, after which each litter pool produces DOC based on its specific decomposition rate, temperature, and soil moisture.

TRIPLEX-DOC adopted a two-fold DOC pool approach to DOC decomposition, with labile and recalcitrant fractions 


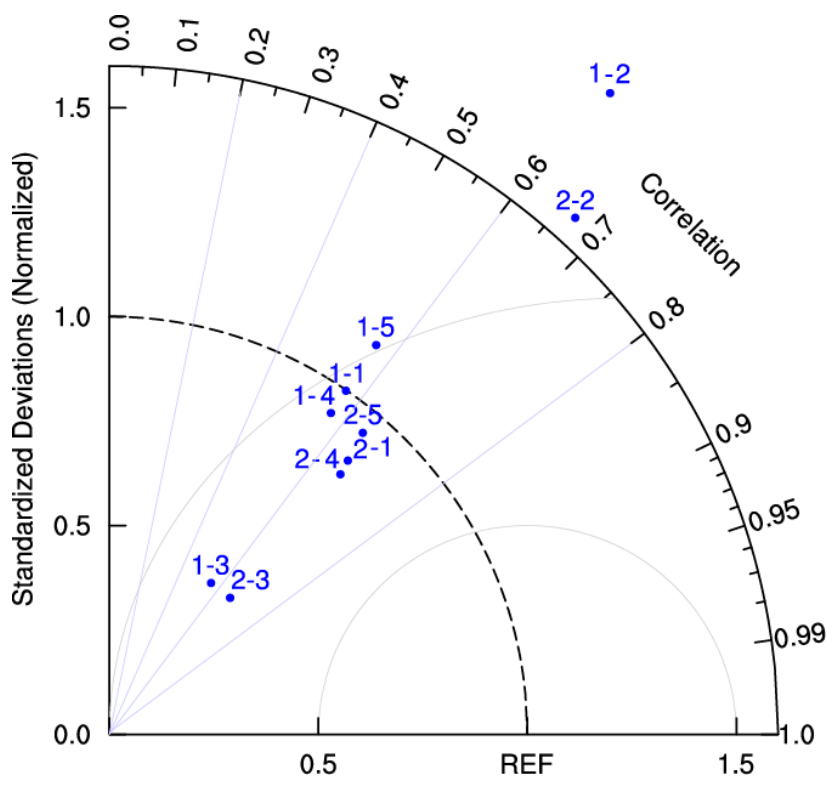

Fig. 7. Sensitivity of DOC concentrations in soils to variation in sorption $(m)$ and desorption $(b)$ parameters using a Taylor diagram. $1-1$ and $2-1$ are standard simulation in Ah layer and in litter layer, $1-2$ and 2-2 are halving value of $m$ in Ah layer and in litter layer, 1-3 and 2-3 are doubling value of $m$ in Ah layer and in litter layer, $1-4$ and 2-4 are halving value of $b$ in Ah layer and in litter layer, and 1-5 and 2-5 are doubling value of $b$ in Ah layer and in litter layer (all values respective of the mentioned layers).

and based on the two-component exponential decay model (Qualls and Haines, 1992; Kalbitz et al., 2003; Kiikkila et al., 2006; McDowell et al., 2006). In contrast, the DyDoc model (Michalzik et al., 2003) is composed of three humic fractions corresponding approximately to hydrophilic (Hum1), hydrophobic acids (Hum-2), and humic acid and aged humin (Hum-3) for which metabolic transformations are described with first-order decay. The DOC model (Neff and Asner, 2001) only comprises a DOC pool, recycling into soil microbial biomass. Another difference between the models is that DyDOC tracks ${ }^{14} \mathrm{C}$ through a plant-soil-water system, thereby providing additional timescale information, but TRIPLEX-DOC confines itself to an overall daily DOC leaching flux.

\subsection{Environmental controls on DOC production and transport}

Knowledge of factors and processes that regulate DOC production and transport in forest soils is important for the prediction of soil $\mathrm{C}$ cycles under a varying climate. Production of DOC in the forest litter layer is thought to be primarily controlled by biological processes (e.g., decomposition of litter, humus, and root exudation), suggesting a high sensitivity to changes in soil temperature and moisture (Kalbitz et al., 2000). Simulations carried out for this study showed a seasonal pattern, the highest DOC concentration occurring in summer in the litter layer and in the Ah layers (Fig. 4). These predications are consistent with results from field observations (Michalzik and Matzner, 1999; Solinger et al., 2001; Kaiser et al., 2002) and laboratory studies (Clark and Gilmour, 1983; Christ and David, 1996; Gödde et al., 1996; Moore et al., 2008), which documented a generally increasing DOC production with increasing soil temperature and moisture. DOC concentrations are higher in the growing season than in non-growing seasons mainly because of the greater microbial activity in response to higher temperatures and moisture of the forest floor (Kalbitz et al., 2000; Yano et al., 2000; Kaiser et al., 2001).

Our results revealed a strong relationship between water flux and DOC flux in all soil layers, exhibiting linear relationships when summed to weekly fluxes (Fig. 8). These results are to be expected since DOC and water move in unison, but they imply that hydrologic flux rather than production mechanisms are the limiting factors of DOC flux. Results were similar to the conclusions based on DOC model simulations (Neff and Asner, 2001) and confirmed by a plot-scale experiment carried out in the field (Tipping et al., 1999), reporting an increase in DOC flux with increasing amounts of water passing through the soil.

\subsection{Impact of land use on DOC leachate}

Understanding the effects of land use change on DOC concentrations and export is imperative when attempting to predict large-scale $\mathrm{C}$ dynamics and changes in landscape $\mathrm{C}$ budgets. Large areas have undergone land use change through forest regeneration and more recently through afforestation on marginal agricultural land, affecting ecosystem $\mathrm{C}$ dynamics (Quideau and Bockheim, 1997; Khomutova et al., 2000; Mattson et al., 2005). TRIPLEX-DOC successfully simulated increases in DOC concentrations in solutions obtained from the litter floor and Ah layer with the increasing age of forest stands (Fig. 4) accompanied with an increasing accumulation of tree and forest floor biomass. Despite higher DOC concentrations found in soil solutions of older stands, results suggest that soil DOC leaching may be decreased by up to 4-fold for the 65-year-old stand (Fig. 6) compared to a recently established forest stand (2-year-old). This decrease in DOC leaching was mainly attributable to a decline in water loss due to increased water uptake by forest evapotranspiration, indicating the importance of hydrological controls on DOC processes.

TRIPLEX-DOC predicted a significant increase (approximately 4-fold) in DOC leaching from soil following removal of $50 \%$ of trees compared pre-removal conditions (Fig. 9). This result is in general agreement with results from a number of studies that measured increased DOC export or concentrations (by 2- to 5-fold) in watershed soil water shortly after logging (Plamondon et al., 1982; Hinton et al., 1997; Startsev et al., 1998). This increase in DOC leaching may 

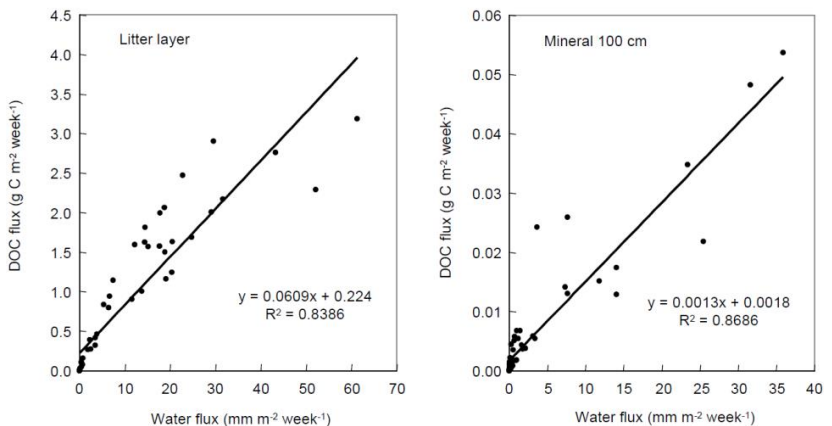

Fig. 8. Relationship between weekly soil DOC flux and water flux in litter layer and mineral soil.

be attributable to the quantity of biomass (leaves, stem, and roots) left on the ground and soil, which is considered to be a primary source of increased DOC concentration and flux (Qualls, 2000; Piirainen et al., 2002). On the other hand, an increase in microbial activity could also be responsible for increased forest DOC concentrations and flux after forest harvesting. This is because temperature and moisture, critical factors for microbial activity, generally increase after harvesting due to more open canopy and reduction in evapotranspiration from the root zone (Londo et al., 1999) and may result in an increased production of DOC (Kalbitz et al., 2000; Kaiser et al., 2001; Neff and Asner, 2001). Water flux also contributes to the release of soil DOC (Kalbitz et al., 2000; Judd and Kling, 2002). It is important to note that forest canopy interception of precipitation and evapotranspiration would decrease after harvesting, increasing water flux to soils and thus resulting in an increase in soil DOC leaching.

\section{Conclusion and future improvements}

TRIPLEX-DOC is a useful tool when quantifying DOC concentrations and leaching in temperate forest soils as well as in predicting how changes in land use may impact DOC. It is compatible with most ecosystem models related to soil C dynamics and forest growth, and provides an effective way to integrate forest management effects and DOC leaching in forest soils at an ecosystem level. Validation and sensitivity tests demonstrated that TRIPLEX-DOC is capable of simulating DOC processes for forest stands of different ages to a reasonable accuracy. The model provides an insight into the mechanisms that control soil DOC concentrations and export, and may be useful in scaling up DOC leaching from landscape to regional scales. Furthermore, this process-based model can be used to project DOC concentrations and leaching under future climate scenarios.

DOC simulation in this study includes the DOC production from throughfall. Although the interception simulation (Rutter et al., 1971) represents the physically based process

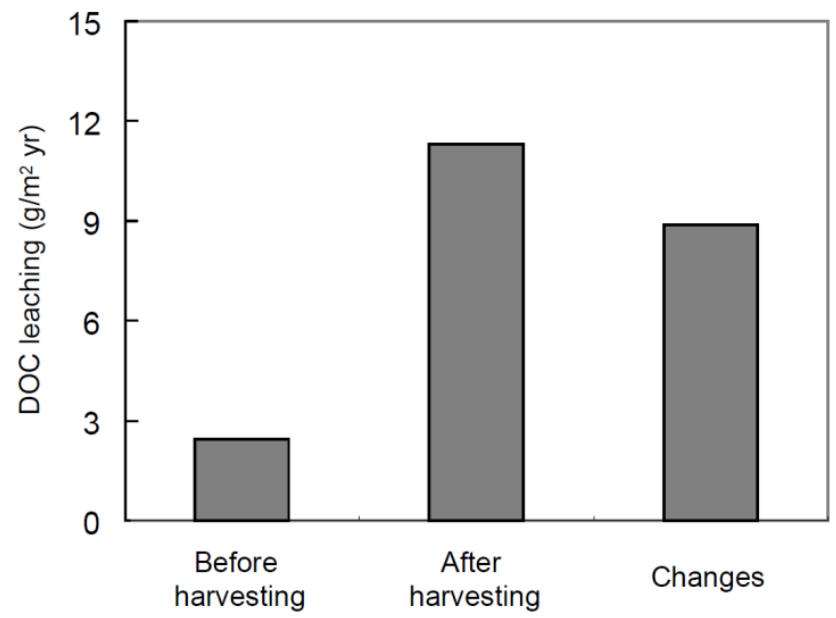

Fig. 9. Sensitivity analysis on the effects of land use on annual DOC leaching before and after $50 \%$ forest harvesting.

by a running water balance of rainfall input, storage, and output in the form of drainage and evaporation, the interception loss depends strongly on the timing and intensity of rainfall, the vegetation structure, and the meteorological conditions controlling evaporation during and after rainfall (Rutter et al., 1975; Dingman, 2002; Brutsaert, 2005). As the Rutter et al. (1971) model used in this study was only treated as a simplified process based on a single-layer vertical vegetation structure and a constant storage capacity, further improvements need to involve more-detailed interception processes in the future.

TRIPLEX-DOC recognizes the role of DOC consumption and sorption/desorption as two key mechanisms that regulate DOC concentrations and export rates. Although our simulations do not provide a more detailed validation of the DOC submodel for different forest types, results indicate that DOC consumption and sorption/desorption-based soil submodels can reasonably capture general patterns in DOC concentration and flux rates related to soil depth, at least for temperate pine forests that we studied and where observed DOC flux data were available. Results also underscore the need for more detailed field experiment studies related to different types of forest ecosystems in major climatic regions and DOC sorption/desorption results from TRIPLEX-DOC are limited due to the model's use of an equilibrium distribution constant rather than using a time-dependent dynamical process (Qualls, 2000). This last point reflects the fact that TRIPLEX-DOC is in the early stage of model development as it pertains to DOC sorption/desorption and improvements could be made by incorporating more dynamic DOC sorption/desorption processes in more realistic ways.

With the future coupling of TRIPLEX-DOC and geographic information systems (GIS), which would contribute a detailed database of regional soil distribution, climate characteristics, and land use patterns, it is anticipated that the 
new model could be a useful tool in improving not only estimations of net $\mathrm{C}$ flux and greenhouse gas (GHG) emissions from forest soils on a regional scale but also DOC export from soils. As the DOC from terrestrial ecosystem is critical to $\mathrm{C}$ budgets in the aquatic ecosystems, this estimate of DOC export will improve our understanding of the connectivity between terrestrial and aquatic $\mathrm{C}$ cycles, reducing the uncertainty in $\mathrm{C}$ fluxes of entire lake-watershed systems. TRIPLEX-DOC would take advantage of the TRIPLEXGHG simulator (Peng et al., 2013) as well as important C loss pathways entering into aquatic ecosystems (TRIPLEXAquatic model) as described in an accompanying paper by Wu et al. (2013). Coupling the two efforts would be a strong contribution to understanding the processing and partitioning of organic $\mathrm{C}$ across both terrestrial and aquatic $\mathrm{C}$ cycles, resulting in a full regional integration between terrestrial and aquatic ecosystems.

Acknowledgements. This study was funded by the National Basic Research Program of China (973 Program) (2010CB950204, 2013CB956602), the Canadian Foundation for Climate and Atmospheric Sciences (CFCAS), the National Natural Science Foundation of China (no. 41071055 and 41125011), the Bairen Programs of the Chinese Academy of Sciences, the Natural Sciences and Engineering Research Council of Canada (NSERC) Discovery Grant, and the Canada Research Chair Program. Measurements at the Turkey Point Flux Station were funded by the Discovery and Strategic Projects Program of (NSERC) and BIOCAP Canada. Additional support provided by the Canadian Foundation of Innovation (CFI), the Ontario Innovation Trust (OIT), McMaster University, and the Ontario Ministry of Natural Resources (OMNR) is also acknowledged in establishing the Turkey Point sites.

Edited by: A. Ridgwell

\section{References}

Aber, J. D. and Federer, C. A.: A generalized, lumped-parameter model of photosynthesis, evaporation and net primary production in temperate and boreal forest ecosystems, Oecologia, 92, 463474, 1992.

Aitkenhead, J. A. and McDowell, W. H.: Soil C:N ratio as a predictor of annual riverine DOC flux at local and global scales, Global Biogeochem. Cy., 14, 127-138, 2000.

Aitkenhead, J. A., Hope, D., and Billett, M. F.: The relationship between dissolved organic carbon in streamwater and soil organic carbon pools at different spatial scales, Hydrol. Process., 13, 1289-1302, 1999.

Arain, M. A. and Restrepo-Coupe, N.: Net ecosystem production in a temperate pine plantation in southeastern Canada, Agr. Forest Meterol., 128, 223-241, 2005.

Band, L. E., Tague, C. L., Groffman, P., and Belt, K.: Forest ecosystem processes at the watershed scale: hydrological and ecological controls of nitrogen export, Hydrol. Process., 15, 2013-2028, 2001.
Boyer, E. W., Hornberger, G. M., Bencala, K. E., and McKnight, D.: Overview of a simple model describing variation of dissolved organic carbon in an upland catchment, Ecol. Modell., 86, 183188, 1996.

Brutsaert, W.: Hydrology. Cambridge University Press, New York, 605 pp., 2005.

Buffam, I., Monicag, T., Ankur, R. D., Paul, C. H., James, A. R., Noah, R. L., Emily, H. S., and Stephen, R. C.: Integrating aquatic and terrestrial components to construct a complete carbon budget for a north temperate lake district, Glob. Change Biol., 17, 11931211, 2011.

Butman, D. and Raymond, P. A.: Significant efflux of carbon dioxide from streams and rivers in the United States, Nat. Geosci., 4, 839-842, 2011.

Chapin III, F. S., Mcguire, A. D., Randerson, J., Pielkesr, R., Baldocchi, D., Hobbie, S. E., Roulet, N., Eugster, W., Kasischke, E., Rastetter, E. B., Zimov, S. A., and Running, S. W.: Arctic and boreal ecosystems of western North America as components of the climate system, Glob. Change Biol., 6, 211-223, 2000.

Chapin III, F. S., Woodwell, G. M., Randerson, J. T., Rastetter, E. B., Lovett, G. M., Baldocchi, D. D., Clark, D. A., Harmon, M E., Schimel, D. S., Valentini, R., Wirth, C., Aber, J. D., Cole, J. J., Goulden, M. L., Harden, J. W., Heimann, M., Howarth, R. W., Matson, P. A., McGuire, A. D., Melillo, J. M., Mooney, H. A., Neff, J. C., Houghton, R. A., Pace, M. L., Ryan, M. G., Running, S. W., Sala, O. E., Schlesinger, W. H., and Schulze, E. D.: Reconciling carbon-cycle concepts, terminology, and methods, Ecosystem, 9, 1041-1050, 2006.

Christ, M. J. and David, M. B.: Temperature and moisture effects on the production of dissolved organic carbon in a spodosol, Soil Biol. Biochem., 28, 1191-1199, 1996.

Clair, T. A. and Ehrman, J. M.: Variations in discharge and dissolved organic carbon and nitrogen export from terrestrial basins with changes in climate: A neural network approach, Limnol. Oceanogr., 41, 926-927, 1996.

Clair, T. A., Pollock, T. L., and Erhman, J. M.: Exports of carbon and nitrogen from river basins in Canada's Atlantic provinces, Global Biogeochem. Cy., 8, 441-450, 1994.

Clark, M. D. and Gilmour, J. T.: The effect of temperature on decomposition at optimum and saturated soil water contents, Soil Sci. Soc. Am. J., 47, 927-929, 1983.

Cole, J. J., Prairie, Y. T., Caraco, N. F., McDowell, W. H., Tranvik, L. J., Striegl, R. G., Duarte, C. M., Kortelainen, P., Downing, J. A., Middelburg, J. J., and Melack, J.: Plumbing the global carbon cycle: integrating inland waters into the terrestrial carbon budget, Ecosystems, 10, 171-184, doi:10.1007/s10021-006-9013-8, 2007.

Currie, W. S. and Aber, J. D.: Modeling leaching as a decomposition process in humid montane forests, Ecology, 78, 1844-1860, 1997.

Dahm, C. N.: Pathways and mechanisms for removal of dissolved organic carbon from leaf leachate in streams, Can J. Fish Aquat. Sci., 39, 68-76, 1981.

Dai, M. H., Yin, Z. Q., Feifei Meng, F. F., Qian Liu, Q., and Cai, W. J.: Spatial distribution of riverine DOC inputs to the ocean: an updated global synthesis, Curr. Opin. Een. Sust., 4, 170-178, 2012.

Dai, Z. H., Trettin, C. C., Li, C. S., Li, H., Sun, G., and Amatya, D. M.: Effect of assessment scale on spatial and temporal variations 
in $\mathrm{CH}_{4}, \mathrm{CO}_{2}$, and $\mathrm{N}_{2} \mathrm{O}$ fluxes in a forested wetland, Water Air Soil Poll., 223, 253-265, 2012.

del Giorgio, P. A., Cole, J. J., Caraco, N. F., and Peters, R. H.: Linking planktonic biomass and metabolism to net gas fluxes in northern temperate lakes, Ecology, 80, 1422-1431, 1999.

Dillon, P. J. and Molot, L. A.: Effect of landscape form on export of dissolved organic carbon, iron and phosphorous from forested stream catchments, Water Resour. Res., 33, 2591-2600, 1997.

Dingman, S.: Physical Hydrology, Prentice Hall, Upper Saddle River, 646 pp., 2002.

Dunn, A. L., Barford, C. C., Wofsy, S. C., Goulden, M. L., and Daube, B. C.: A long-term record of carbon exchange in a boreal black spruce forest: Means, responses to interannual variability, and decadal trends, Glob. Change Biol., 13, 577-590, 2007.

Eckhardt, B. and Moore, T. R.: Controls on dissolved organic carbon concentrations in streams, southern Quebec, Can. J. Fish Aquat. Sci., 47, 1537-1544, 1990.

Gödde, M., David, M. B., Christ, M. J., Kaupenjohann, M., and Vance, G. F.: Carbon mobilization from the forest floor under red spruce in the northeastern USA, Soil Biol. Biochem., 28, 11811189, 1996.

Grimm, N. B., Gergal, S. E., McDowell, W. H., Boyer, E. W., Dent, C. L., Groffman, P., Hart, S. C., Harvey, J., Johnston, C., Mayorga, E., Mcclain, M. E., and Pinay, G.: Merging aquatic and terrestrial perspectives of nutrient biogeochemistry, Oecologia, 137, 485-501, 2003.

Guggenberger, G., Zech, W., and Schulten, H.: Formation and mobilization pathways of dissolved organic matter: evidence from chemical structural studies of organic matter fractions in acid forest floor solutions, Org. Geochem., 21, 51-66, 1994.

Hanson, P. C., Pollard, A. I., Bade, D. L., Predick, K., Carpenter, S. R., and Foley, J. A.: A model of carbon evasion and sedimentation in temperate lakes, Glob. Change Biol., 10, 1285-1298, 2004.

Harrison, J. A., Caraco, N., and Seitzinger, S. P.: Global patterns and sources of dissolved organic matter export to the coastal zone: results from a spatially explicit, global model, Glob. Biogeochem. Cy., 19, GB4S04, doi:10.1029/2005GB002480, 2005.

Hinton, M. J., Schiff, S. L., and English, M. C.: The significance of storms for the concentration and export of dissolved organic carbon from two Precambrian Shield catchments, Biogeochemistry, 36, 67-88, 1997.

Hope, D., Billett, M. F., Milne, R., and Brown, T. A. W.: Exports of organic carbon in British rivers, Hydrol. Process., 11, 325-344, 1997.

Humborg, C., Morth, C. M., Sundbom, M., Borg, H., Blenckner, T., Giesler, R., and Ittekkot, V.: $\mathrm{CO}_{2}$ supersaturation along the aquatic conduit in Swedish watersheds as constrained by terrestrial respiration, aquatic respiration and weathering, Glob. Change Biol., 16, 1966-1978, 2010.

Jandl, R. and Sollins, P.: Water-extractable soil carbon in relation to the belowground carbon cycle, Biol. Fert. Soils, 25, 196-201, 1997.

Jenerette, G. D. and Lal, R.: Hydrologic sources of carbon cycling uncertainty throughout the terrestrial-aquatic continuum, Glob. Change Biol., 11, 1873-1882, 2005.

Judd, K. E. and Kling, G. W.: Production and export of dissolved $\mathrm{C}$ in arctic tundra mesocosms: the roles of vegetation and water flow, Biogeochemistry, 60, 213-234, 2002.
Kaiser, K. and Kalbitz, K.: Cycling downwards-dissolved organic matter in soils, Soil Biol. Biochem., 52, 29-32, 2012.

Kaiser, K. and Zech, W.: Soil dissolved organic matter sorption as influenced by organic and sesquioxide coating and sorbed sulfate, Soil Sci. Soc. Am. J., 62, 129-136, 1998.

Kaiser, K., Guggenberger, G., and Zech, W.: Sorption of DOM and DOM fractions to forest soils, Geoderma, 74, 281-303, 1996.

Kaiser, K., Guggenberger, G., Haumaier, L., and Zech, W.: Seasonal variations in the chemical composition of dissolved organic carbon in organic forest floor layer leachates of old-growth Scots pine (Pinus sylvestris L.) and European beech (Fagus sylvatica L.) stands in northeastern Bavaria, Germany, Biogeochemistry, 55, 103-143, 2001.

Kaiser, K., Guggenberger, G., Haumaier, L., and Zech, W.: The composition of dissolved organic matter in forest soil solutions: changes induced by seasons and passage through the mineral soil, Org. Geochem., 33, 307-318, 2002.

Kalbitz, K., Solinger, S., Park, J. H., Michalzik, B., and Matzner, E.: Controls on the dynamics of dissolved organic matter in soils: a review, Soil Sci., 165, 277-304, 2000.

Kalbitz, K., Schmerwitz, J., Schwesig, O., and Matzner, E.: Biodegradation of soil derived dissolved organic matter as related to its properties, Geoderma, 113, 273-291, 2003.

Kesik, M., Ambus, P., Baritz, R., Brüggemann, N., ButterbachBahl, Damm, K., Duyzer, M. J., Horváth, L., Kiese1, R., Kitzler, B., Leip, A., Li, C., Pihlatie, M., Pilegaard, K., Seufert, S., Simpson, D., Skiba, U., Smiatek, G., Vesala, T., and ZechmeisterBoltenstern, S.: Inventories of $\mathrm{N}_{2} \mathrm{O}$ and $\mathrm{NO}$ emissions from European forest soils, Biogeosciences, 2, 353-375, 2005, http://www.biogeosciences.net/2/353/2005/.

Khomutova, T. E., Richter, J., Shirshova, L. T., Tinz, S., and Rolland, W.: Mobilization of DOC from sandy loamy soils under different land use (Lower Saxony, Germany), Plant Soil, 219, 13-19, 2000.

Kiese, R., Li, C., Hilbert, D. W., Papen, H., and Butterbach-Bahl, K.: Regional application of PnET-N-DNDC for estimating the $\mathrm{N}_{2} \mathrm{O}$ source strength of tropical rainforests in the Wet Tropics of Australia, Glob. Change Biol., 11, 128-144, 2005.

Kiikkila, O., Kitunen, V., and Smolander, A.: Dissolved soil organic matter from surface organic horizons under birch and conifers: Degradation in relation to chemical characteristics, Soil Biol. Biochem., 38, 737-746, 2006.

Kosten, S., Roland, F., Marques, D., Van Nes, E. H., Mazzeo, N., Sternberg, L. D. L., Scheffer, M., and Cole, J. J.: Climatedependent $\mathrm{CO}_{2}$ emissions from lakes, Global Biogeochem. Cy., 24, GB2007, doi:10.1029/2009GB003618, 2010.

Kothawala, D. N., Moore, T. R., and Hendershot, W. H.: Soil properties controlling adsorption of dissolved organic carbon to mineral soils, Soil Sci. Soc. Am. J., 73, 1831-1842, 2009.

Kreutzweiser, D. P., Hazlett, P. W., and Gunnb, J. M.: Logging impacts on the biogeochemistry of boreal forest soils and nutrient export to aquatic systems: A review, Environ. Rev., 16, 157-179, 2008.

Lapierre, J. F. and del Giorgio, P. A.: Geographical and environmental drivers of regional differences in the lake $p \mathrm{CO}_{2}$ versus DOC relationship across northern landscapes, J. Geophys. Res., 117, G03015, doi:10.1029/2012JG001945, 2012. 
Li, C., Frolking, S., and Frolking, T. A.: A model of nitrous oxide evolution from soil driven by rainfall events, 1 . Model structure and sensitivity, J. Geophys. Res., 97, 9759-9776, 1992.

Li, C. S., Aber, J., Stange, F., Butterbach-Bah, K., and Papen, H.: A process-oriented model of $\mathrm{N}_{2} \mathrm{O}$ and $\mathrm{NO}$ emissions from forest soils: 1. Model development, J. Geophys. Res., 105, 4369-4384, 2000.

Londo, A. J., Messina, M. G., and Schoenholtz, S. H.: Forest harvesting effects on soil temperature, moisture, and respiration in a bottomland hardwood forest, Soil Sci. Soc. Am. J., 63, 637-644, 1999.

Lumsdon, D. G., Stutter, M. I., Cooper, R. J., and Manson, J. R.: Model assessment of biogeochemical controls on dissolved organic carbon partitioning in an acid organic soil, Environ. Sci. Technol., 39, 8057-8063, 2005.

Mattson, T., Kortelainen, P., and Räike, A.: Export of DOM from boreal catchments: impacts of land use cover and climate, Biogeochemistry, 76, 373-394, 2005.

Marschner, B. and Kalbitz, K.: Controls of bioavailability and biodegradability of dissolved organic matter in soils, Geoderma, 113, 211-235, 2003.

McCallister, S. L. and del Giorgio, P. A.: Direct measurement of the $\delta^{13} \mathrm{C}$ signature of carbon respired by bacteria in lakes: Linkages to potential carbon sources, ecosystem baseline metabolism, and $\mathrm{CO}_{2}$ fluxes, Limnol. Oceanogr., 53, 1204-1216, 2008.

McDowell, W. H., Zsolnay, A., Aitkenhead-Peterson, J. A., Gregorich, E. G., Jones, D. L., Jödemann, D., Kalbitz, K., Marschner, B., and Schwesig, D.: A comparison of methods to determine the biodegradable dissolved organic matter (DOM) from different terrestrial sources, Soil Biol. Biochem., 38, 1933$1942,2006$.

Michalzik, B. and Matzner, E.: Dynamics of dissolved organic nitrogen and carbon in a Central European Norway spruce ecosystem, Eur. J. Soil Sci., 50, 579-590, 1999.

Michalzik, B., Kalbitz, K., Park, J. H., Solinger, S., and Matzner, E.: Fluxes and concentrations of dissolved organic carbon and nitrogen-a synthesis for temperate forests, Biogeochemistry, 52, 173-205, 2001.

Michalzik, B., Tipping, E., Mulder, J., Gallardo Lancho, J. F., Matzner, E., Bryant, C. L., Clarke, N., Lofts, S., and Vicente Esteban, M. A.: Modelling the production and transport of dissolved organic carbon in forest soils, Biogeochemistry, 66, 241264, 2003.

Moore, T. R., de Souza, W., and Koprivnjak, J. F.: Controls on the sorption of dissolved organic carbon by soils, Soil Sci., 154, 120 129, 1992.

Moore, T. R., Paré, D., and Boutin R.: Production of dissolved organic carbon in Canadian forest soils, Ecosystems, 11, 740-751, 2008.

Neff, J. C. and Asner, G. P.: Dissolved organic carbon in terrestrial ecosystems: synthesis and a model, Ecosystems, 4, 29-48, 2001.

Nelson, P. N., Baldock, J. A., and Oades, J. M.: Concentration and composition of dissolved organic carbon in streams in relation to catchment soil properties, Biogeochemistry, 19, 27-50, 1993.

Nodvin, S. C., Driscoll, C. T., and Likens, G. E.: Simple partitioning of anions and dissolved organic carbon in a forest soil, Soil Sci., 142, 27-35, 1986.
Peichl, M. and Arain, M.: Above- and belowground ecosystem biomass and carbon pools in an age-sequence of planted white pine forests, Agr. Forest Meteorol., 140, 51-63, 2006.

Peichl, M., Moore, T. R., Arain, M. A., Dalva, M., Brodkey, D., and McLaren, J.: Concentrations and fluxes of dissolved organic carbon in an age-sequence of white pine forests in Southern Ontario, Canada, Biogeochemistry, 86, 1-17, 2007.

Peichl, M., Arain, M. A., and Brodeur, J. J.: Age effects and climatic controls on carbon fluxes in pine forests, Agr. Forest Meterol., 150, 1090-1101, 2010.

Peng, C. H., Zhu, Q., and Chen, H.: Integrating greenhouse gas emission processes into a dynamic global vegetation model: TRIPLEX-GHG model development and testing. In the proceeding of 4th NACP All-Investigators Meeting, 64 pp., 4-7 February, Albuquerque, NM, USA, 2013.

Piirainen, S., Finer, L., Mannerkoski, H., and Starr, M.: Effects of forest clear-cutting on the carbon and nitrogen fluxes through podzolic soil horizons, Plant Soil, 239, 301-311, 2002.

Plamondon, A. P., Gonzalez, A., and Thomassin, Y.: Effects of logging on water quality: Comparison between two Quebec sites, in: Proceedings of the Canadian Hydrological Symposium'82, National Research Council of Canada, Ottawa, Ont., 49-70, 1982.

Prendergast, J. B.: Soil water bypass and solute transport under irrigated pasture, Soil Sci. Soc. Am. J., 59, 1531-1539, 1995.

Presant, E. W. and Acton, C. J.: The soils of the regional municipality of Haldimand-Norfolk, Vol. 1, Report No. 57, Agriculture Canada, Ministry of Agriculture and Food, Guelph, Ontario, 100 pp., 1984.

Qualls, R. G.: Comparison of the behavior of soluble organic and inorganic nutrients in forest soils, Forest Ecol. Manage., 138, 29 50,2000

Qualls, R. and Haines, B. L.: Biodegradability of dissolved organic matter in forest throughfall, soil solution, and stream water, Soil Sci. Soc. Am. J., 56, 578-586, 1992.

Qualls, R. G., Haines, B. L., and Swank, W. T.: Fluxes of dissolved organic nutrients and humic substances in a deciduous forest, Ecology, 72, 254-266, 1991.

Quideau, S. A. and Bockheim, J. G.: Biogeochemical cycling following planting to red pine on a sandy prairie soil, J. Environ. Qual., 26, 1167-1175, 1997.

Radulovich, R., Sollins, P., Baveye, P., and Solorzano, E.: Bypass water flow through unsaturated microaggregated tropical soils, Soil Sci. Soc. Am. J., 56, 721-726, 1992.

Raymond, P. A. and Saiers, J. E.: Event controlled DOC export from forested watersheds, Biogeochemistry, 100, 197-209, 2010.

Roehm, C. L., Prairie, Y. T., and del Giorgio, P. A.: The $p \mathrm{CO}_{2}$ dynamics in lakes in the boreal region of northern Quebec, Canada, Global Biogeochem. Cy., 23, GB3013, doi:10.1029/2008GB003297, 2009.

Rutter, A. J., Kershaw, K. A., Robins, P. C., and Morton, A. J.: A predictive model of rainfall interception in forest, I. Derivation of the model from observation in a plantation of Corsican pine, Agr. Meteorol., 9, 367-384, 1971.

Rutter, A., Morton, A., and Robins, P.: A predictive model of rainfall interception in forests. II. Generalization of the model and comparison with observations in some coniferous and hardwood stands, J. Appl. Ecol., 12, 367-380, 1975. 
Sobek, S., Algesten, G., Bergstrom, A. K., Jansson, M., and Tranvik, L. J.: The catchment and climate regulation of $p \mathrm{CO}_{2}$ in boreal lakes, Glob. Change Biol., 9, 630-641, 2003.

Solinger, S., Kalbitz, K., and Matzner, E.: Controls on the dynamics of dissolved organic carbon and nitrogen in a Central European deciduous forest, Biogeochemistry, 55, 327-349, 2001.

Startsev, N. A., McNabb, D. H., and Startsev, A. D.: Soil biological activity in recent clearcut in west-central Alberta, Can. J. Soil Sci., 78, 69-76, 1998.

Sun, G., Li, C., Trettin, C., Lu, J., and McNulty, S. G.: Simulating the biogeochemical cycles in cypress wetland-pine upland ecosystems at a landscape scale with the Wetland-DNDC Model, in: Proceedings of the International Conference on Hydrology and Management of Forested Wetlands, 8-12 April, New Bern, NC, 261-270, 2006.

Taylor, K. M.: Summarizing multiple aspects of model performance in a single diagram, J. Geophys. Res., 106, 7183-7192, 2001.

Tipping, E., Woof, C., Rigg, E., Harrison, A. F., Inneson, P., Taylor, K., Benham, D., Poskitt, J., Rowland, A. P., Bol, R., and Harkness, D. D.: Climatic influences on the leaching of dissolved organic matter from upland UK moorland soils, investigated by a field manipulation experiment, Environ. Inter., 25, 83-95, 1999.

Trolle, D., Staehr, P. A., Davidson, T. A., Bjerring, R., Lauridsen, T. L., Søndergaard, M., Jeppesen, E.: Seasonal dynamics of $\mathrm{CO}_{2}$ flux across the surface of shallow temperate lakes, Ecosystems, 15, 336-347, 2012.

Turgeon, J.: Production and biodegradation of dissolved carbon, nitrogen and phosphorus from Canadian forest floors, Ph.D thesis, McGill University, Montréal, 2008.
Vandenbruwane, J., Neve, S. D., Qualls, R. G., Sleutel, S., and Hofman, G.: Comparison of different isotherm models for dissolved organic carbon (DOC) and nitrogen (DON) sorption to mineral soil, Geoderma, 139, 144-153, 2007.

Weigand, H. and Totsche, K. U.: Flow and reactivity effects on dissolved organic matter transport in soil columns, Soil Sci. Soc. Am. J., 62, 1268-1274, 1998.

Wu, H., Peng, C., Lucotte, M., Soumis, N., Gélinas, Y., Duchemin, É., Plouhinec, J.-B., Ouellet, A., and Guo, Z.: A coupled twodimensional hydrodynamic and terrestrial input model to simulate $\mathrm{CO}_{2}$ diffusive emissions from lake systems, Geosci. Model Dev. Discuss., 6, 3509-3556, doi:10.5194/gmdd-6-3509-2013, 2013.

Xu, N., Saiers, J. E., Wilson, H. F., and Raymond, P. A.: Simulating streamflow and dissolved organic matter export from a forested watershed, Water Resour. Res., 48, W05519, doi:10.1029/2011WR011423, 2012.

Yano, Y., McDowell, W. H., and Kinner, N. E.: Quantification of biodegradable dissolved organic carbon in soil solution with flow-through bioreactors, Soil Sci. Soc. Am. J., 62, 1556-1564, 1998.

Yano, Y., McDowell, W. H., and Aber, J. D.: Biodegradable dissolved organic carbon in forest soil solution and effects of chronic nitrogen deposition, Soil Biol. Biochem., 32, 1743 1751, 2000.

Zsolnay, A. and Steindl, H.: Geovariability and biodegradability of the water-extractable organic material in an agricultural soil, Soil Biol. Biochem., 23, 1077-1082, 1991. 